\title{
A perplexing rash
}

\author{
Manish Praful Ranpara, ${ }^{1}$ Paul Devakar Yesudian ${ }^{2}$
}

${ }^{1}$ Cochrane Medical Education Centre, Cardiff University School of Medicine, Cardiff, UK

${ }^{2}$ Department of Dermatology, Glan Clwyd Hospital, Rhyl, UK

\section{Correspondence to}

Manish Praful Ranpara, one_manish_ranpara@yahoo. com

Accepted 18 August 2015

\section{DESCRIPTION}

A 69-year-old woman presented to the emergency department with a painful rash of 5 weeks duration. The rash started as two discrete erythematous plaques on the left medial malleolus and was treated as cellulitis by her general practitioner. Despite antibiotic treatment, the skin condition worsened and spread to her chest, abdomen, and upper and lower limbs. The patient had a history of Crohn's disease for which she had started azathioprine 3 weeks prior to presentation, and poorly controlled type 2 diabetes that required insulin. On examination, she had erythematous plaques on the trunk and limbs, some of which had coalesced to form larger plaques in the lower limbs (figures 1 and 2). The rest of her systemic examination was unremarkable. The differential diagnosis considered in the Acute Medical Unit (AMU) included an adverse cutaneous drug reaction to azathioprine, erythema nodosum and insect bites. The patient's azathioprine and clindamycin were stopped and a specialist review was requested. The dermatology team reviewed her and made a clinical diagnosis of Sweet's syndrome secondary to inflammatory bowel disease. A punch biopsy from the rash on the left arm revealed papillary dermal oedema and an upper dermal infiltrate of neutrophils with leucocytoclasia, consistent with Sweet's syndrome. ${ }^{1}$

First described by Robert Douglas Sweet in $1964,{ }^{2}$ Sweet's syndrome, or acute febrile neutrophilic dermatosis, is a constellation of neutrophilia,

CrossMark

To cite: Ranpara MP, Yesudian PD. BMJ Case Rep Published online: [please include Day Month Year] doi:10.1136/bcr-2015211792

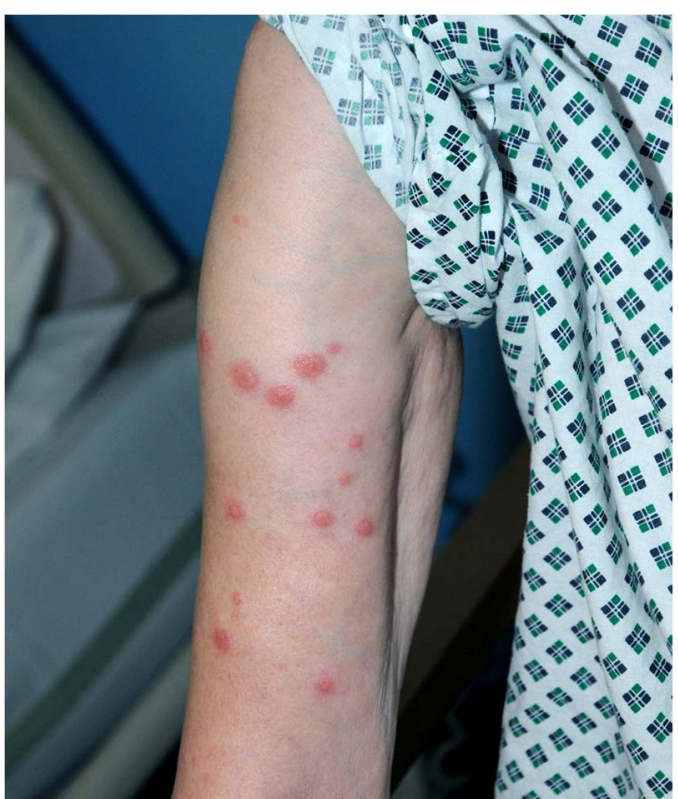

Figure 1 Raised, discrete erythematous plaques on the right arm. Similar lesions were present on the trunk.

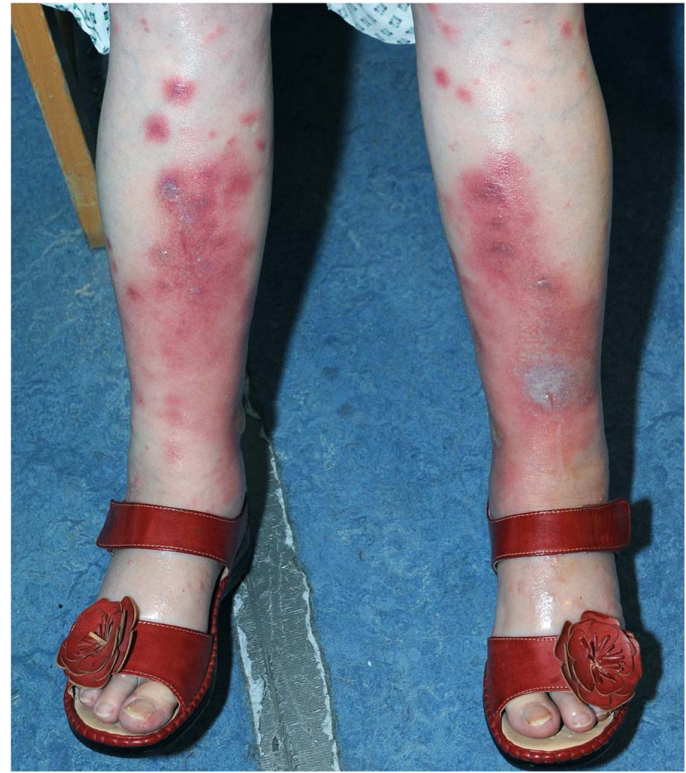

Figure 2 The erythematous plaques coalesced to form larger ones in the lower limbs.

fever and erythematous plaques with a neutrophilic infiltrate on histology. It can be associated with malignancies, inflammatory bowel disease and drugs. The pathogenesis of this condition is unclear. Topical or systemic corticosteroids are the cornerstone of therapy, but potassium iodide and colchicines can also be considered. ${ }^{12}$

Our patient made a full recovery within 5 days of applying topical clobetasol propionate (a potent topical steroid) on the lesions.

\section{Learning points}

- Sweet's syndrome is an uncommon rash that can be a manifestation of inflammatory bowel disease.

- To the non-dermatologist, it can be difficult to diagnose and is often mistaken for an infective condition, such as cellulitis.

Competing interests None declared.

Patient consent Obtained.

Provenance and peer review Not commissioned; externally peer reviewed.

\section{REFERENCES}

1 Cohen PR. Sweet's syndrome - a comprehensive review of an acute febrile neutrophilic dermatosis. Orphanet J Rare Dis 2007;2:34.

2 Sweet RD. An acute febrile neutrophilic dermatosis. Br J Dermato 1964;76:349-56. 
Copyright 2015 BMJ Publishing Group. All rights reserved. For permission to reuse any of this content visit http://group.bmj.com/group/rights-licensing/permissions.

BMJ Case Report Fellows may re-use this article for personal use and teaching without any further permission.

Become a Fellow of BMJ Case Reports today and you can:

- Submit as many cases as you like

- Enjoy fast sympathetic peer review and rapid publication of accepted articles

- Access all the published articles

- Re-use any of the published material for personal use and teaching without further permission

For information on Institutional Fellowships contact consortiasales@bmjgroup.com

Visit casereports.bmj.com for more articles like this and to become a Fellow 